Presented at the 138th National

Meeting of the Electrochemical

Society, Symposium on "Fundamental

Aspects of Electrochemical Machining,"

Atlantic City, New Jersey, Oct. 4-9, 1970
UCRL-19618

Preprint

Conf $701016 \ldots 1$

\title{
PERIODIC PHENOMENA IN COPPER DISSOLUTION \\ AT CONSTANT CURRENT
}

J. Cooper, R.H. Muller, and C.W. Tobias

October 1970

AEC Contract No. W -7405 -eng -48
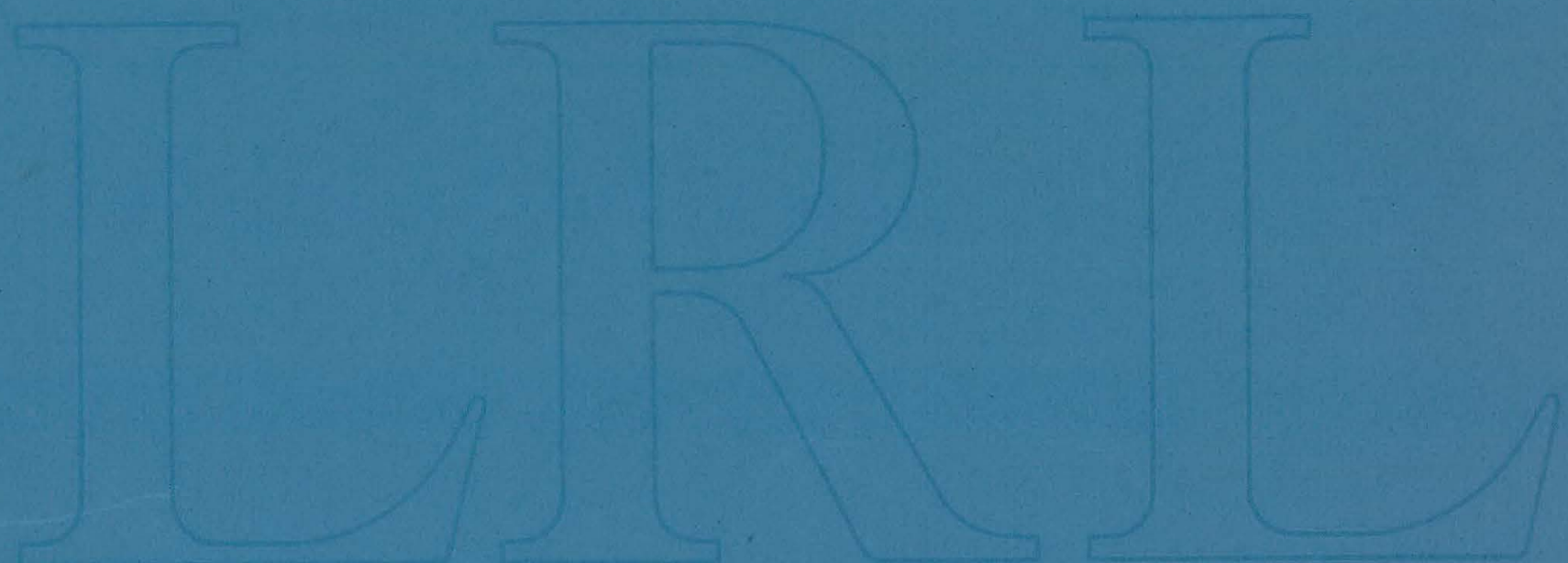

LAWRENCE RADIATION LABORATORY UNIVERSITY of CALIFORNIA BERKELEY 


\section{DISCLAIMER}

This report was prepared as an account of work sponsored by an agency of the United States Government. Neither the United States Government nor any agency Thereof, nor any of their employees, makes any warranty, express or implied, or assumes any legal liability or responsibility for the accuracy, completeness, or usefulness of any information, apparatus, product, or process disclosed, or represents that its use would not infringe privately owned rights. Reference herein to any specific commercial product, process, or service by trade name, trademark, manufacturer, or otherwise does not necessarily constitute or imply its endorsement, recommendation, or favoring by the United States Government or any agency thereof. The views and opinions of authors expressed herein do not necessarily state or reflect those of the United States Government or any agency thereof. 


\section{DISCLAIMER}

Portions of this document may be illegible in electronic image products. Images are produced from the best available original document. 


\title{
PERIODIC PHENOMENA IN COFPER DISSOLUTION AT CONSTANT CURRENT
}

\author{
J. Cooper, R. H: Muller and C. W. Tobias \\ Inorganic Materials Research Division, Lawrence Radiation Laboratory, \\ and Departments of Chemistry and Chemical Engineering, \\ University of California, Berkeley, California 94720
}

\begin{abstract}
Anode potential fluctuations have been observed in high rate galvanostatic dissolution of copper in different electrolytes. The fluctuations are most pronounced and periodic in chlorate solutions. Variations in apparent valence of the dissolution process, in the products formed and in the surface temperature, have been determined in the course of one cycle. While a complete description of the mechanism of dissolution is not, as yet, possible, a theoretical model has been developed which accounts for the observed phenomena.
\end{abstract}

\section{LEGAL NOTICE}

Nork This report was prepared as an Government. Neither This report by the United States Government. Nenthergy sponsored the United States nor the their employees, nor any of Commission, nor any of thactors, or their employes, their contractors, subcuntsactor implied, or assumes any makes any warranty, express or implity for the accuracy, comlegal liability or responsibility for the

pleteness or usefuiness disclosed. or represents

would not infringe privately owned rights 
Electrode potential oscillations in galvanostatic electrolysis (or current density oscillations in potentiostatic electrolysis) have long been observed for a variety of electrode-electrolyte combinations. Bonhoeffer and Langhammer, and Franck have studied such processes in detail and their work has been summarized by Vetter. ${ }^{I}$ These oscillations have been connected with changes between active and passive electrode states brought about by corresponding changes in local electrolyte concentration and $\mathrm{pH}$.

Anode potential oscillations have also been observed in high current density dissolution of copper in chlorate, chloride, nitrate, and sulfate solutions. ${ }^{2,3}$ These oscillations are most prominent and most accessible to interpretation in sodium chlorate electrolytes and may be connected with the desirable properties of the chlorate solutions used in electrochemical machining. 4 


\section{Experimental}

Electrolysis experiments were conducted in two different cells. The first (Fig. I) was designed for operation under natural convection conditions. Anodes used in this cell were $2-3 \mathrm{~mm}$ thick cylindrical disks with surfaces of $10 \mathrm{~cm}^{2}$ facing upward into the anolyte chamber. Cathodes were made of copper mesh, with approximately $25 \mathrm{~cm}^{2}$ total surface area, positioned $2.3 \mathrm{~cm}$ above the anode, and separated from the anode with a filter paper diaphragm.

The second cell (Fig. 2) was designed for operation under forced convection conditions. Two 3 by $3 \mathrm{~mm}$ square electrodes were spaced $1 \mathrm{~mm}$ apart, flush with the walls of the flow channel, with the anode facing upward: Glass plates, forming the walls of the flow channel, afforded visual observation of the electrode surface during dissolution. Flow velocities ranging from 14 to $600 \mathrm{~cm} / \mathrm{sec}$ were employed. Potential-time measurements were recorded on a light-beam oscillograph.*

Oxygen-free copper $(99.99 \%)$ and reagent grade sodium chlorate were used.

\section{Observations}

Well-defined periodic fluctuations in the ariode potential were observed when the applied current was held constant at values above about $0.5 \mathrm{~A} / \mathrm{cm}^{2}$. The frequency of the oscillations increased and the shape of the cycle changed with increasing current density, as shown. schematically in Fig. 3.

The relationship between current density and oscillation period and its weak dependence on flow velocity is shown in Fig. 4.

* Series 2300, Brush Instrument Division, Cleveland, Ohio. 
At current densities below about $3 \mathrm{~A} / \mathrm{cm}^{2}$, an individual oscillation period, T, may be divided into phases I and II (Fig. 5). Phase II contains a low potential region and a potential peak. Phase I diminishes rapidly in length with increase of current density and vanishes above about $5 \mathrm{~A} / \mathrm{cm}^{2}$. Unlike the total oscillation period, the length of phase I does not appear to be affected by electrolyte flow velocity:

The potential cycles were found to reflect the periodic growth and rupture of anode films. Analysis of a motion picture of the growth process in $3 \mathrm{~N} \mathrm{NaClO}_{3}$ revealed that the anode film thickens approximately linearly with time throughout both low and peak potential regions, as shown in Fig. 6. The rupture of the film and the rapid outward movement of the solid products was shown to coincide with the abrupt drop from peak potentials. In the case illustrated in Fig. 6, a blue-green film grew to a thickness of 150 microns in 0.5 seconds and then exploded from the surface of the metal within the last 0.03 seconds of the cycle.

The apparent valence of the electrode process and the X-ray dfffraction patterns of anode films were studied in order to elucidate the composition of the films. The apparent valence of dissolution was determined from electrode weight-loss measurements. The experiments were performed in stationary solutions at current densities of 0.53 and $1.33 \mathrm{~A} / \mathrm{cm}^{2}$. Tu ublain the instantaneous apparent valence, electrolysis. was torminatcd at different points within a single cycle. The instantaneous apparent valence of dissolution, determined from the slope of the weight-loss curve, shown in Fig. 7, clearly distinguishes phase I from phase II. -. Above about. $5 \mathrm{~A} / \mathrm{cm}^{2}$, the apparent valence or dissolution averaged over many oscillations approached a constant value of 1.2 and showed no 
dependence on electrolyte flow velocity.

The strongly adherent film produced in phase I was shown by X-ray powder diffraction to consist exclusively of cuprous oxide. Phase II films were weakly adherent and showed evidence of cupric chlorate and its basic salts ${ }^{* *}$ as well as cuprous oxide.

Throughout both phases, the presence of cupric and chloride ions has been detected in solution.

Discussion

The following model is proposed as a tentative explanation for the periodic phenomena observed: In neutral or slightly aridic solutions, and on oxide-free surfaces, phase I dissolution produces a porous, adherent film of cuprous oxide by the reaction,

$$
\mathrm{Cu}+1 / 2 \mathrm{H}_{2} \mathrm{O}=1 / 2 \mathrm{Cu}_{2} \mathrm{O}+\mathrm{H}^{+}+1 \mathrm{e}^{-} \text {. }
$$

Under these conditions, cuprous oxide is llitimodynomically favoren over the divilenl cupper ion ae a dissnintion pruduct. ${ }^{6}$ The oneet of phase II dissolution is marked by the production of a thick blanket precipitate of hasic clupric chlorate, which adheres loosely to the surface of the metal. The process probably involves the chemical oxidation of $\mathrm{Cu}_{2} \mathrm{O}$ by the chlorate ion,

$$
1 / 2 \mathrm{Cu}_{2} \mathrm{O}+1 / 6 \mathrm{ClO}_{3}^{-}+\mathrm{H}^{+}=\mathrm{Cu}^{++}+1 / 6 \mathrm{CI}^{-}+\mathrm{OH}^{-}
$$

which is favored by the accumulation of hydrogen ions and heat within the pores of the original $\mathrm{Cu}_{2} \mathrm{O}$ film.

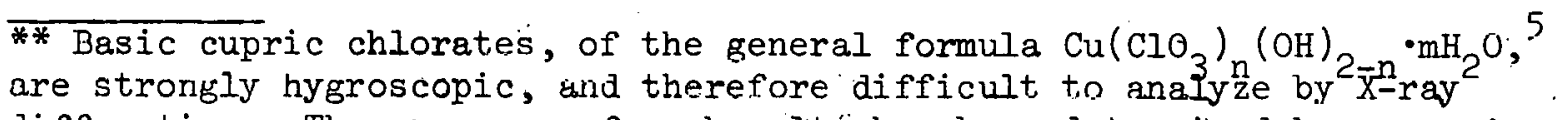
diffraction. The presence of such sults has been determined by comparison of the diffraction patterns with those of prepared samples. 
On the basis of this model, a decrease in $\mathrm{pH}$ is expected to diminish the rate of growth of the film of basic salts. The oscillation period does in fact increase with bulk hydrogen ion concentration (Fig: 8). Also consistent with this model is the observed lengthening of oscillation period with increase in flow rate, due to the accelerated rate of dissolution of soluble reaction products.

The non-integral apparent valences observed may be explained by simultaneous dissolution to both mono- and divalent copper ions.

The potential peaks can be attributed to a decrease in porosity of the anode film, which accelerates as solid dissolution products are continually added. Power dissipation in the residual pore volume then leads to local vaporization of electrolyte, which results in rupture and removal of the film. Such a model is supported by the observed fluffiness of film debris, by the explosive nature of film shedding, and by the fact that the highest rate of temperature increase at the anode coincides with the onset of film breakdown (Fig. 9).

The periodic potential oscillations in the anodic dissolution of copper in.sodium chlorate solutions involve chemical and mass transfer processes which have not, as yet, been thoroughly elucidated. A firmer understanding of the periodic phenomena should evolve as these studics are continucd.

\section{Acknowledgment}

This work was conducted under the auspices of the United States Atomic Energy Commission. 


\section{References}

1. K. J. Vetter, Electrochemical Kinetics, (Academic Press, New York, 1967), p. 786 .

2. K. Kinoshita, Ph. D. Thesis, University of California, Berkeley, 1969.

3. D. Landolt, R. Acosta, R. Muller, and C. W. Tobias, J. Electrochem. Soc., $117,839(1970)$.

4. M. A. LaBoda and M. L. McMillan, Electrochem. Techno1., 2, 340 (1967).

5. D. Royer, J. Kleinberg, and A. Davidson, J. Inorg. Nucl. Chem., 4 , $11.5-127,(1957)$.

6. M. Pourbaix, Atlas of Electrochemical Equilibria in Aqueous Solutions, (Pergemon Press, Oxford, 1966), p. 384. 


\section{Figure Captions}

Fig. 1. Cell for anodic dissolution under natural convection conditions (schematic). A - bolt, B - lucite cell body, C - copper anode, D - teflon seal, E - lucite cell bottom, F - connector pin, G - brase heat sink, H - anolyte chamber, I - filter paper diaphragm, J - copper mesh cathode, $K$ - catholyte chamber.

Fig. 2. Schematic of flow system for copper dissolution under forced convection conditions. A - supply tank, B - dual piston pump, C - accumulator, D - bypass line, E - rotameter, F - entrance length of flow channel, G - reference electrodes, H - cathode, I - anode, J·- capillary for precipitate collection, $\mathrm{K}$ - drain tank.

Fig. 3. Types of potential oscillations in different current density ranges (time axis not to scale).

Fig. 4. Dependence of oscillation period $(T)$ on current density for copper dissolution in $2 \mathrm{~N} \mathrm{NaClO}_{3}$ at two different flow velocities; $\mathrm{pH}=4.6 ;$ temperature $=24^{\circ} \mathrm{C}$.

Fig. 5. Typical voltage trace of a single oscillation cycle. Copper dissolution in $2 \mathrm{~N} \mathrm{NaClO}_{3}, 1.33 \mathrm{~A} / \mathrm{cm}^{2}$, stationary solution.

Fig. 6. Growth of precipitate layer in anodic dissolution of copper in $3 \mathrm{~N} \mathrm{NaClO}_{3}$ at $3.12 \mathrm{~A} / \mathrm{cm}^{2}$. Numbers indlcate tirst, second, etc., potential peaks after the bcginning of electrolysis.

Fig. 7. Change in apparent valence (n) as determined from weight-loss measurements during one cycle; anodic dissolution of copper into stationary solutions of $2 \mathrm{~N} \mathrm{NaClO}_{3}$; current density, $1.33 \mathrm{~A} / \mathrm{cm}^{2}$.

Fig. 8. $\mathrm{pH}$ dependence of oscillation period $(\mathrm{T})$ in $2 \mathrm{~N} \mathrm{NaClO}_{3}, 24^{\circ} \mathrm{C}$. 
Fig. 9. Electrode temperature (measured between back of electrode and heat sink) during three potential oscillation. $\mathrm{Cu} / 2 \mathrm{~N} \cdot \mathrm{NaClO}_{3}$, $1.33 \mathrm{~A} / \mathrm{cm}^{2}$, stationary electrolyte. 


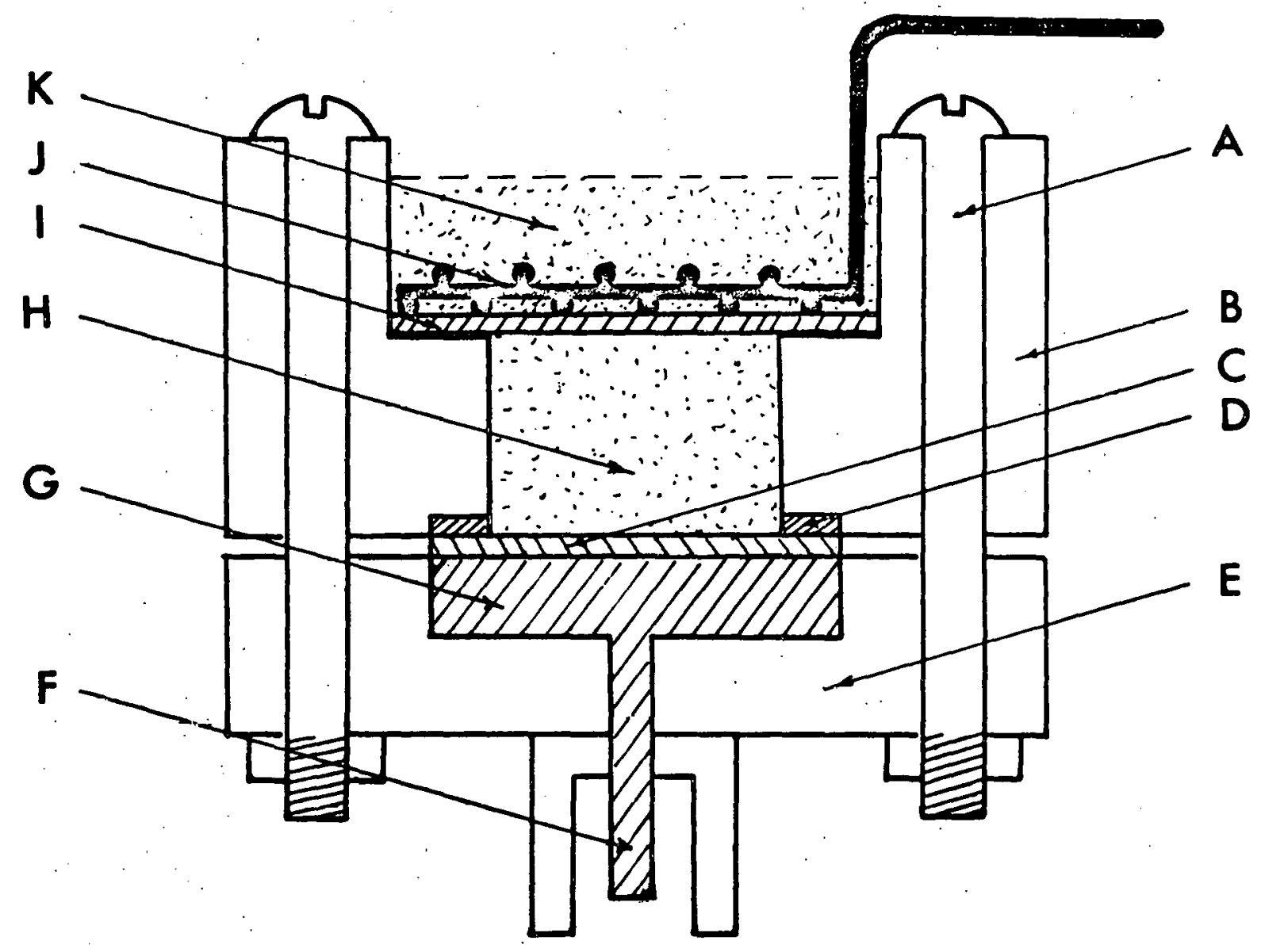

XBL 709-6605

Fig. 1 , 


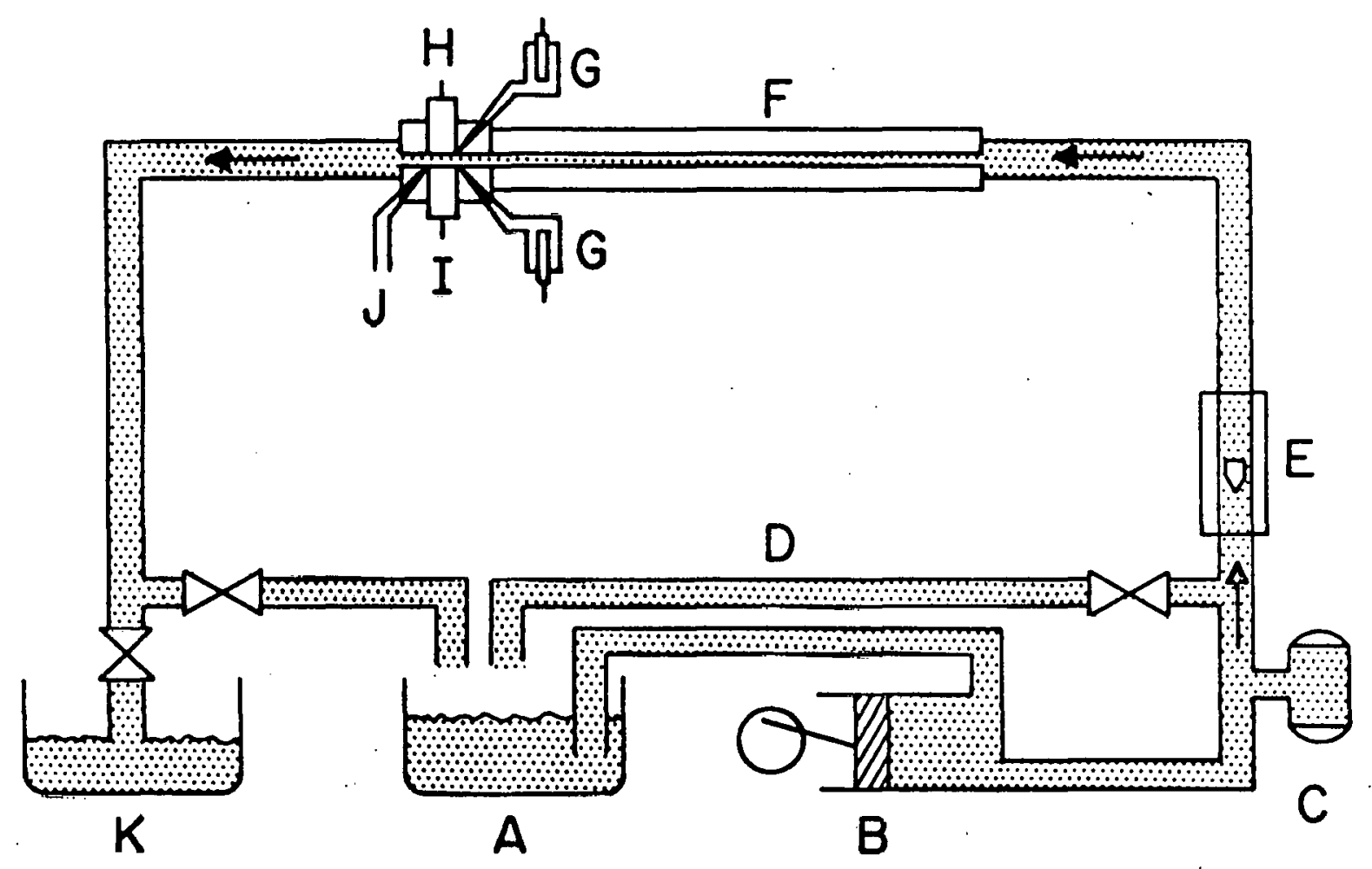

XBL704-2707

Fig. 2 . 


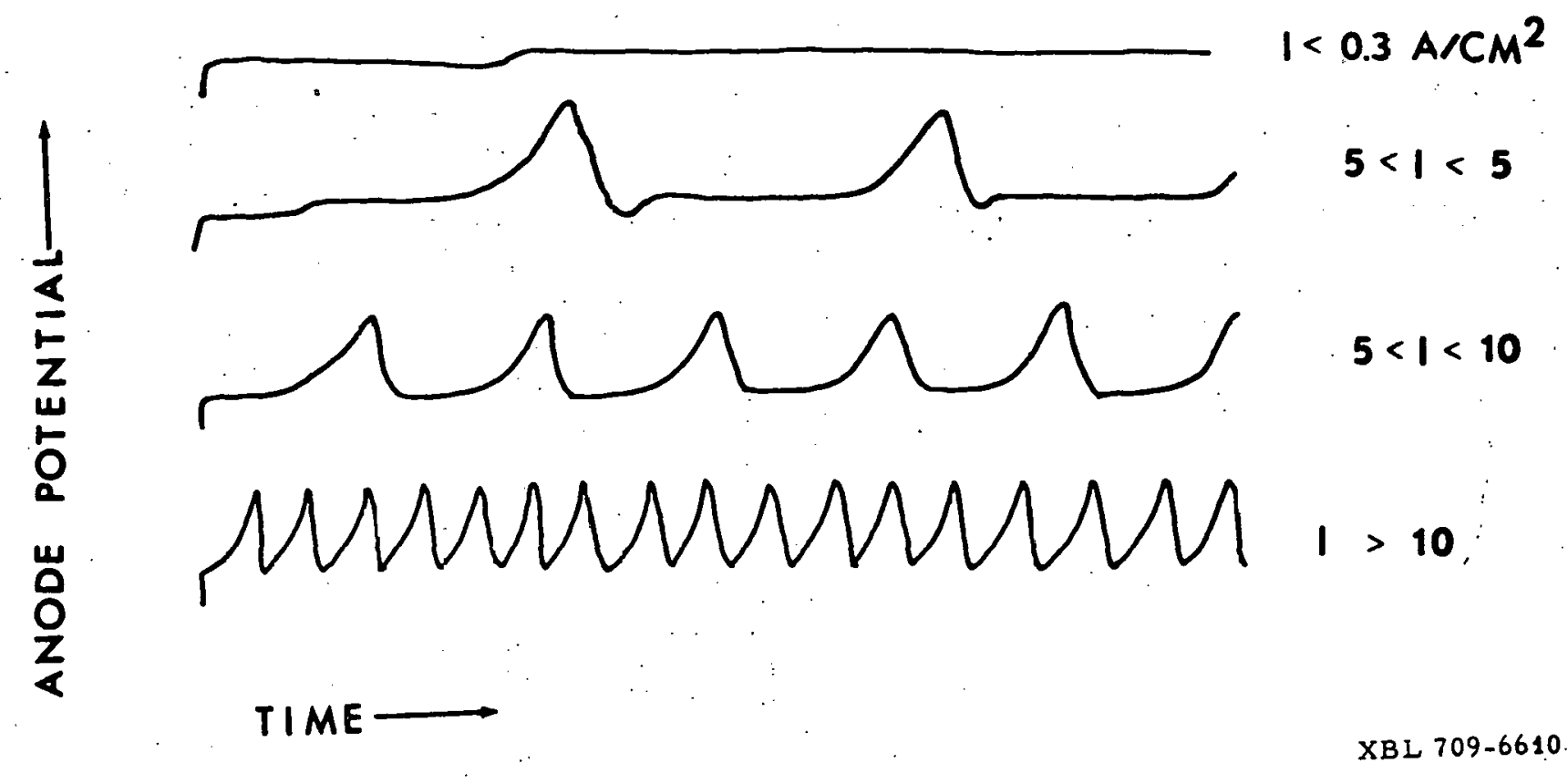

Fig. 3. 


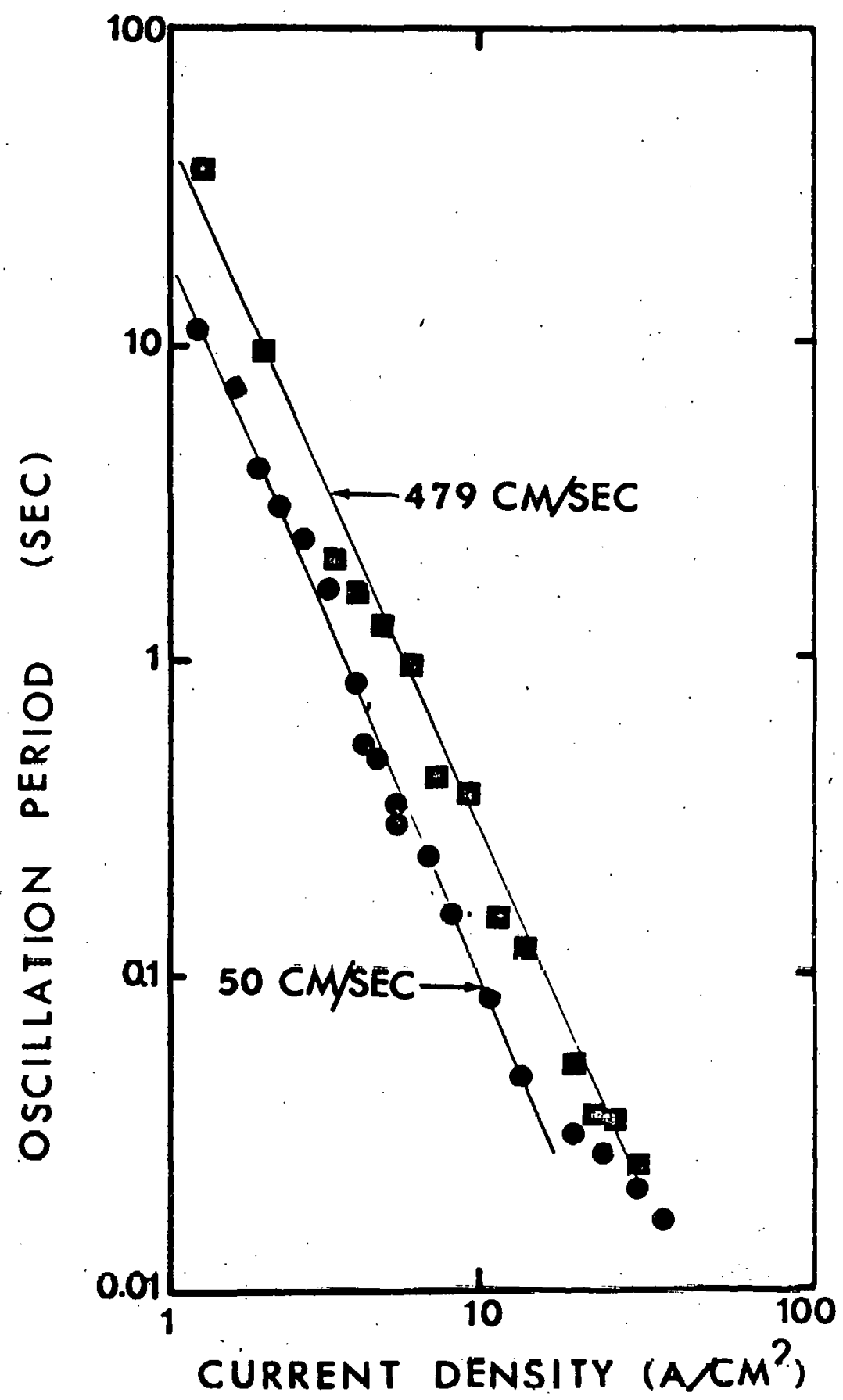

XBL 709-6611

Fig. 4. 


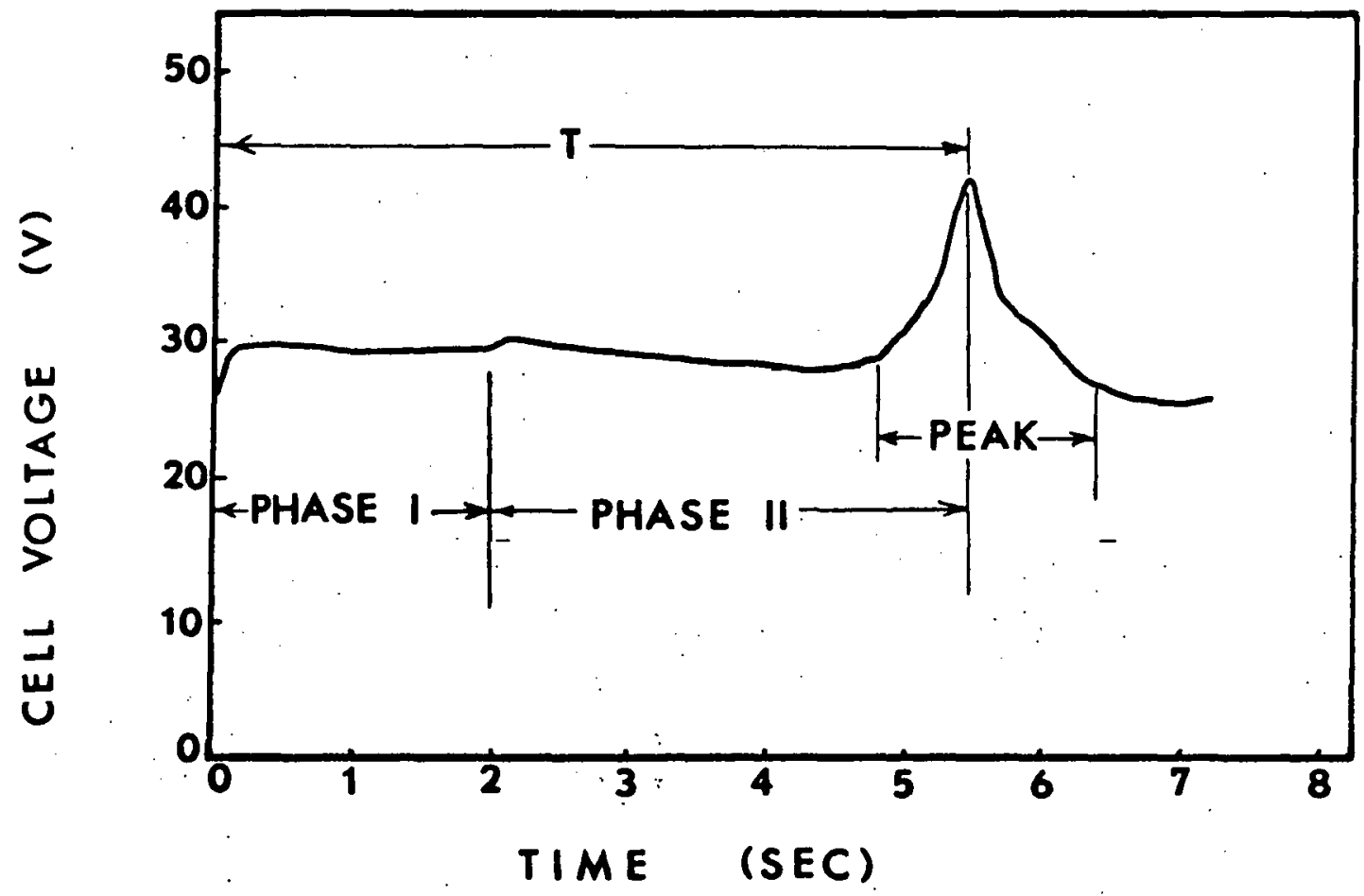

XBL 709-6609

Fig, 5. 


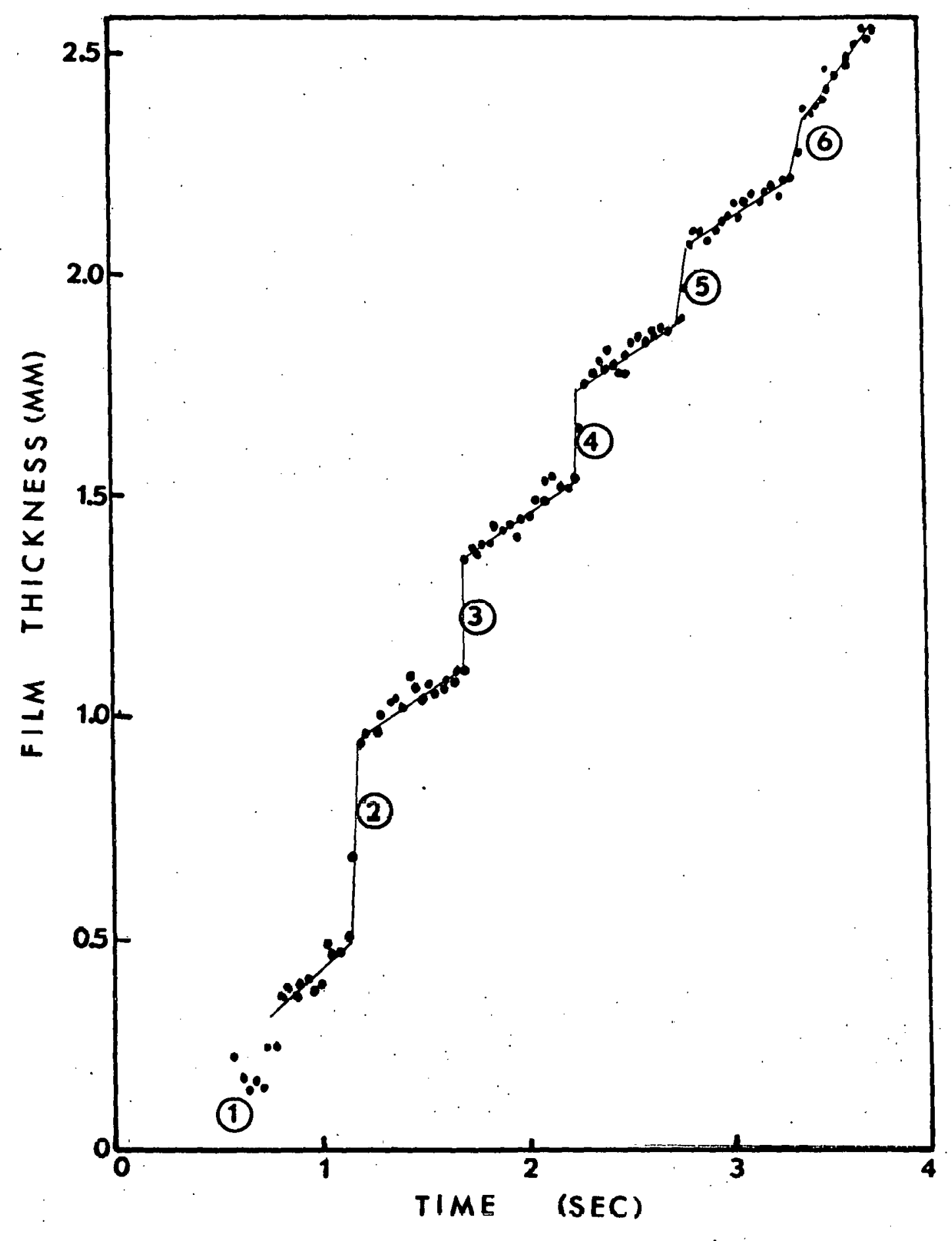

XBL $709-6608$

Fig. 6 


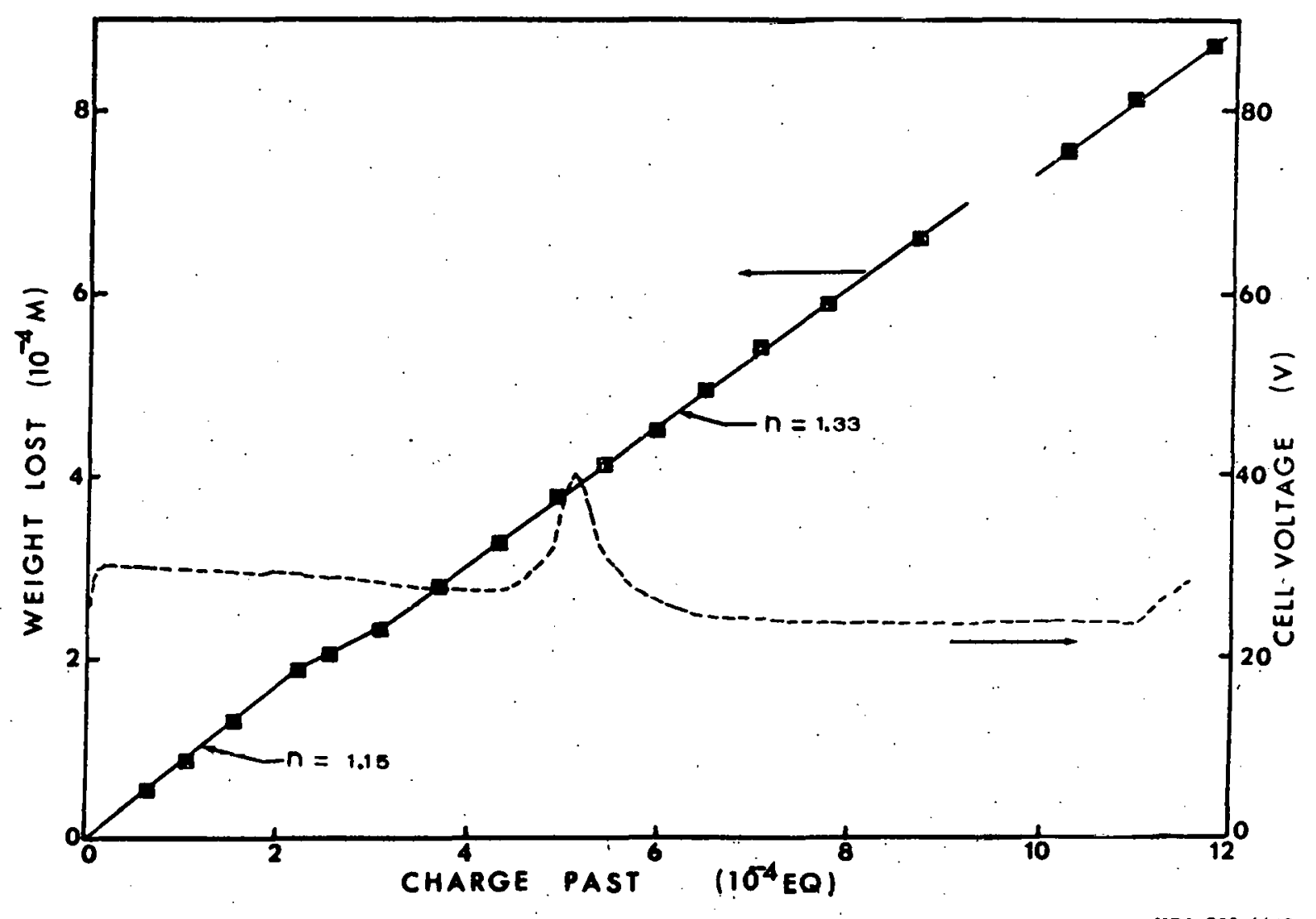

Fig. 7. 


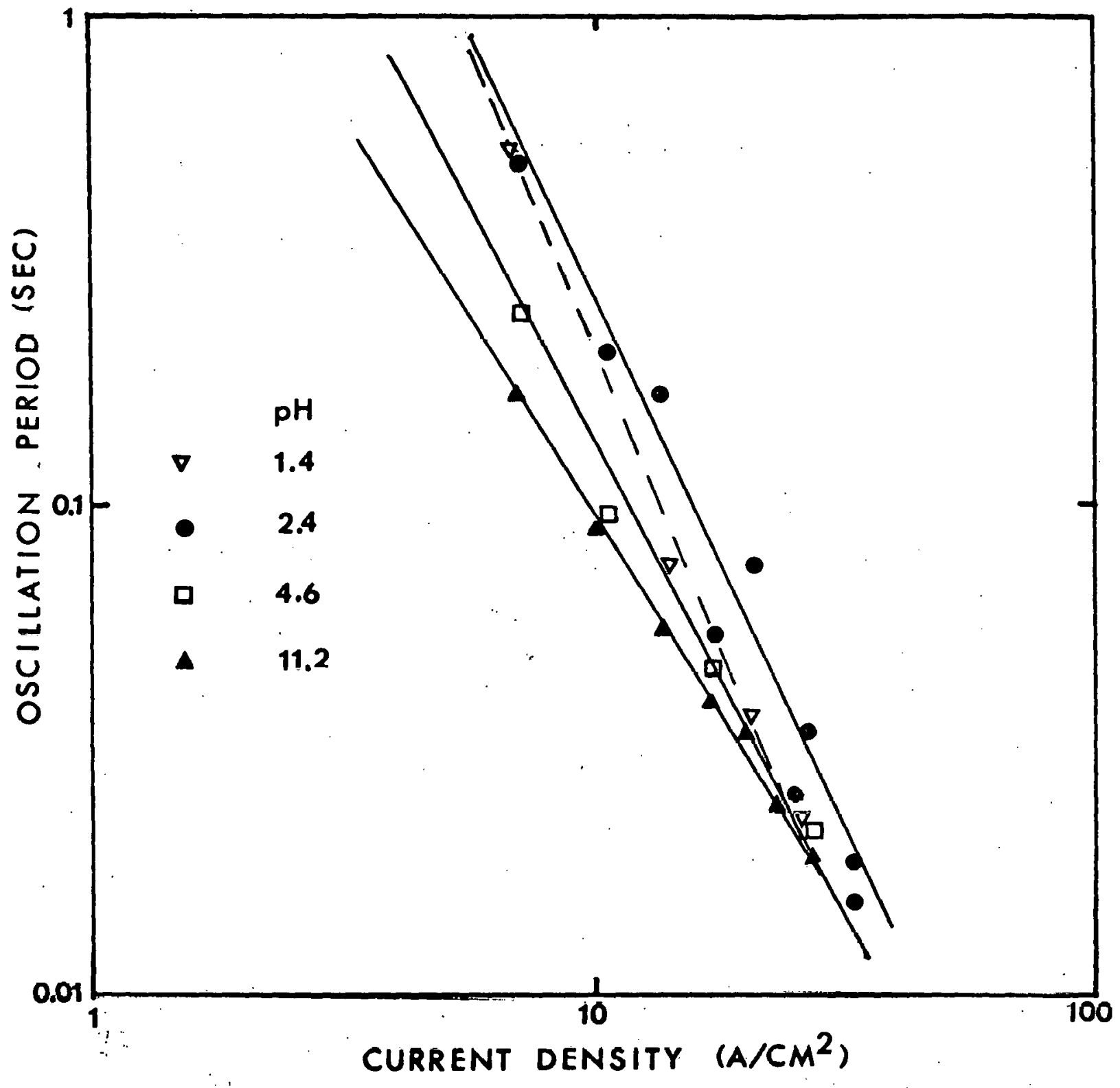

XBL 709-6607

Fig. 8 . 


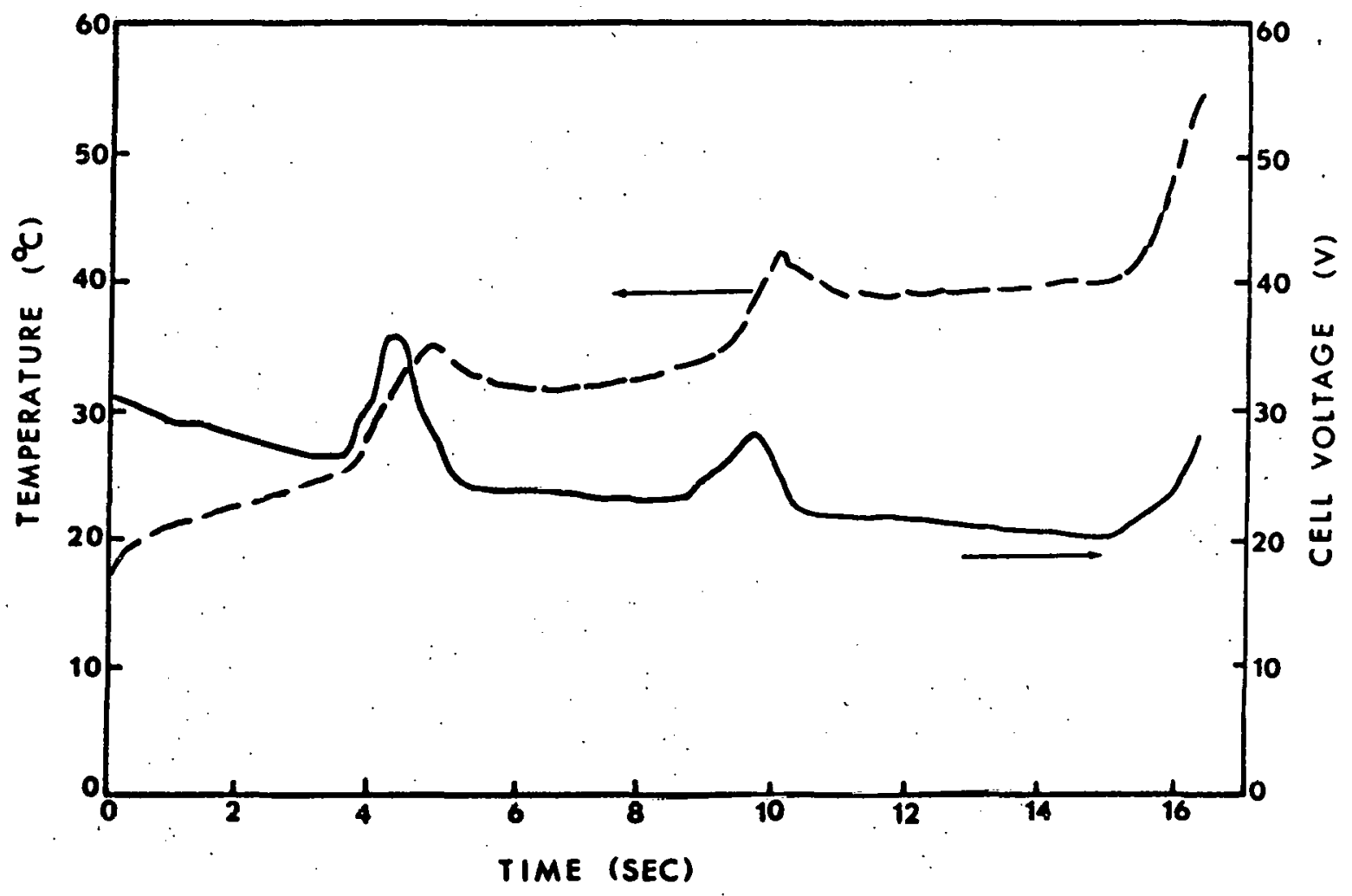

XBL 709-6606

Fig. 9. 
<smiles></smiles> 
